Social Sciences, Humanities and Education Journal (SHE Journal)

Volume 1 (3) 103 - 112, September 2020 | ISSN: 2720-9946 (Online) | ISSN: 2723-3626 (Print)

The article is published with Open Access at: http://e-journal.unipma.ac.id/index.php/SHE

\title{
HYBRIDITY AND OTHERNESS IN ALGERIAN POSTCOLONIAL LITERATURE
}

Neema Ghenim $\bowtie$, Professor in Comparative Literature, Faculty of Foreign Languages, English Section, University of Mohamed Ben Ahmed, Oran 2, Algeria.

Abstract: The paper considers the dualistic existence between the Self and the Other during the Great War. Algerian participation in the war was compulsory and many authors wrote about the event.: Albert Camus, a Frenc hman who belonged to a pied -noir family, Mohamed Ben Chérif, an Arab from Djelfa, and Elissa Rhaïs, a Jewish writer from Blida. The First Man (1994), Camus's book, deals with the French who were reluctant participants in war. Mohamed Ben Chérif also published his first book, Ahmed Ben Mostapha Goumier (1997) that represents those Algerians who sought friendship with the French . In Le Café Chantant (1920) , Elissa Rhaïs gives another picture of an Algerian who participated in the Great War. This paper examines the meeting with the Other that left indelible marks on the protagonists' identities.

Keywords: Hybridity, Otherness, Travel Writing, The Great War.

\ghenimnehmet@hotmail.com

Citation: Ghenim, N. (2020). Hybridity and otherness in algerian postcolonial literature . Social Sciences, Humanities and Education Journal (SHE Journal) $\quad$, 1(3), 103 - 112. DOI: $10.25273 /$ she.v1i3.7615

\section{(cc) $\mathrm{EY}-\mathrm{NG}-\mathrm{SA}$}

Published by Universitas PGRI Madiun. This work is licensed under the Creative Commons Attribution NonCommercialShareAlike 4.0 International License. 


\section{INTRODUCTION}

Algeria is situated in the Maghreb, which means 'the land where the sun sets.' Colonization left indelible marks on the Maghrebian people as, compared to Tunisia and Morocco, both French protectorates, it is in Algeria that the French stayed the longest. The colonisation of Algeria lasted for 132 years. Thus, hybridity is an essential debate within postcolonial studies in Algeria, where both colonized and colonizers went through various experiences that forced the meeting with the Other.

The writers of my selection belong to different backgrounds and have a mixed heritage: Albert Camus, a Frenchman who belongs to a pied-noir family, Mohamed Ben Chérif, an Arab from Djelfa, and Elissa Rhaïs, born to an Algerian Jewish family from Blida. Albert Camus maintains a differentiation from the French since he had never been indifferent to the Algerian natives around him and he assumed a degree of indigenousness. Mohamed Ben Chérif had gone through the Koranic School, nevertheless, he had mainly a French education. He went first to the high school of Algiers and then he became a fellow student of Emir Khaled, the grandson of the great military and religious leader, Emir Abdelkader,in the military school of Saint-Cyr in France. In his autobiographical novel, Ahmed Ben Mostapha Goumier, he wrote about an Algerian soldier, Ben Mostapha, a man who has chosen to fight with the French army to show his extreme devotion to France. Elissa Rhaïs, who is also very conscious of her hybridity, has chosen to recount the misery of the Great War through the experience of an Algerian Muslim family. Even though many Algerian Jews participated in the war as well; Rhaïs preferred to enter the house of the other, not as a stranger but as a native who desired to be friendly and showed extreme sensitivity to the smallest details of the Algerian culture.

These writers are connected to two cultures due to the experience of colonialism that brought together a plethora of distinct identities. This paper shows how the voyage of fictional protagonists intensified their sense of identity. Each narrative voice here speaks about the event, the Great War, either directly or indirectly. These three books embody the Algerian collective memory.

\section{ALBERT CAMUS: THE DIALOGUE BETWEEN THE TWO SIDES OF THE MEDITERRANEAN}

It is believed that Camus's teacher, Mr. Louis Germain, said that truth is found in novels and asked him to write a novel about the Algerian-French conflict after which Camus wrote Le premier homme (the First Man), his last, unfinished novel which was found after his death. Prior to his tragic death in a car accident, Camus had revealed to his wife Francine that his novel's principal objective is to share his nativity with continental France. This book is still raising many questions because it is an unfinished work. Can we take its unpolished nature as a metaphor of the frustration generated by the AlgerianFrench conflict? We can never guess what would be the final form of this novel; consequently we can never know Camus's view of the end of the Algerian-French conflict.

The novel essentially reveals a man who is strongly attached to peace. Right from the opening scene, which recounts the long voyage of Henry Cormery and his wife Lucie, the French and the Algerians are always together in this work. The long journey starts from Algiers to Bone, and then from Bone to the province of Saint Apôtre. As soon as they reach their house, Lucie goes into labour and delivery, and in this very difficult and magnificent moment, we notice an immediate friendship born between the French family and Arabs as they help the woman give birth. There is an aspiration for fraternity when Henry Cormery and Kaddour share a burlap sack to cover themselves from rain. 
In the first chapter, the Cormery family is identified as travellers, "les voyageurs," a nickname that is passed on to their son, "the traveller," "le voyageur," in chapter two. Travelling always intensifies identity awakening, and, accordingly, Jacques Cormery goes through many journeys that help him shape his personality and identity. Following the first chapter, which recounts his birth on the Algerian soil and ends with the parents finally relaxed, sleeping in the silence of the night, "Saint Brieuc," the second chapter, again starts with a voyage; except that it is forty years after, when Jacques arrives at the railway station of Saint Brieuc, and asks for the place of the dead of the First World War. He understands that this place is called "the square of the French remembrance" (Le premier homme 32). The guard who receives him opens a large book covered with wrapping paper, fingers a list of names, and stops at "Cormery, Henry." He notices that Henry's death occurred at Saint Brieuc, the11th of October 1914 and, as Jacques deduces when he reads the dates on the grave, when his father died, at the age of twenty nine, he had been younger than him who was forty. He says: "something here was not in the natural order and, in truth, there was no order but only madness and chaos when the son was older than the father" (34-35). Jacques considers his homeland as the forgotten land where everyone is the first man. He is always curious to learn the slightest detail about his father. He keeps on asking his mother, without much satisfaction (74). He states: "To begin with, poor people's memory is less nourished than that of a rich; it has fewer landmarks in space because they seldom leave the place where they live, and fewer reference points in time throughout lives that are grey and featureless"(93).He tries to piece the puzzle of his father and the Great War, and makes three pilgrimages to three important places: Saint-Brieuc, Algiers, and Mondovi (Dréan), the place of his birth. The historical silence prevails during these visits, nevertheless, he succeeds in finding one person from Mondovi that remembers his father and again he evokes only his silence. The old dealer in Carob tells him that his father was taciturn. Jacques also remembers another important character, Mr. Bernard, his best teacher who, fought for four years in the war and talked to his pupils about the courage of the soldiers of the French army, and the great happiness everyone felt when the armistice was announced. He also read to them a book entitled des Croix de Bois, written by Roland Dorgelès, which narrates the lives of soldiers in the French army and the horrendous conditions during the First World War. Jacques listened with passion to the stories of these very singular men, who were heavily dressed, parts of their clothing stiffened with mud.

Jacques wants to seek other witnesses, so he turns to $\mathrm{M}$. Levesque, the headmaster of his school, and is lucky to find out more about his father. He learns that Henry had been with the Zouaves, (Algerian members of the French army) in Morocco in 1905. M. Levesque also tells him how his father was a serene, taciturn person, and recounts how during a terrible night they both found a colleague with his throat slashed and his sexual organ protruding from his mouth. He narrates how Cormery raged against the inhumanity of this violent act and assumed that men could not have committed such an act; He shouted: "I am poor, I left the orphanage, they dressed me in this uniform, they dragged me into the war, but I would not allow myself to do such a thing" (78). Henry Cormery believed that a man should abstain himself from violence, "Un homme, ças'empêche" (77), and remained distant when he saw the criminality of some acts. For him, a man should always watch himself, particularly in difficult moments like war, when it is easier to succumb to what Hannah Arendt called "the banality of evil." This scene is important because it shows that the enemy has not destroyed Cormery's identity. Instead, his complex situation-of a French-Algerian man fighting with the Zouaves, his Algerian 
partners, for the French cause-impels Cormery to develop and mature a cultural hybridity which is intricate in these cases because it intensifies the sense of belonging and compels negotiation and ambivalence. Cormery does not feel a moral obligation to fight in this war. His reluctance in this defining moment proves that hybridity or binary thinking is a threat for prevailing ideals. This is the voice of a molded character, neither Algerian nor French, an interesting overlap between two cultures due to the colonial encounter. When the Germans declared war on France, Arab and French Algerians were sent into La Marne. In a seemingly unfinished passage that Camus himself wanted to develop further (he writes in the footnotes: 'a déveloper,' "to be developed"), the writer describes La Marne as a carpet full of mud and a sky stuffed with explosive shells where African troops melted under fire like multicoloured wax dolls (82). He recounts the severe financial problems and extreme poverty that was partly caused by the Great War (99), and focuses specifically on the story of a family, the Cormery, that also confronts death. It is interesting to note that when the mayor brings the bad news about Cormery's death, he expresses his sadness and the grief for all France, voicing the pride of France vis-à-vis her loyal soldiers. Accordingly, Lucy, Cormery's wife, receives a letter from her husband's nurse that states that if he had stayed alive Henry would have been crazy or blind, which suggests that death was a blessing in his case. The complex issue of hybridity is underlined when observing the late Cormery, neither a volunteer nor a fervent soldier, to be considered a loyal soldier of France. Yet, Henry was never asked about his deeds and shows ambivalence towards France, which hinders his sense of belonging; therefore it is difficult to assert whether Cormery would have been proud to be considered a hero.

Camus is also concerned with Cormery's son who is left in Algeria. He says: "No, he would never know his father, who would continue to sleep over there, his face forever lost in the ashes"(212-213). Hybridity is very disruptive and constructive at the same time. Jacques grows knowing that his father is buried in Saint-Brieuc and looks at the Mediterranean Sea as a wall that separates the two worlds. One day, while he is landing in the aircraft in Algiers, he recalls the little cemetery of Saint-Brieuc where the graves are better preserved than those of Mondovi and considers how the one dignifies memories and preserves names, while the other obliterates the traces of men. Camus's use of the metaphor of the sandstorm that eliminates all traces of memory over large areas, reinforces this theme and suggests that Jacques had a deeper connection with the greenish graves of Mondovi than those of Saint-Brieuc (214215). In fact, Jacques's love towards France is ambivalent. He is told that his father always considered France as "the homeland," "la patrie, " yet Jacques was too young for this big word and did not even understand the meaning of the phrase when his grandfather told him "Ton pére est mort pour la patrie," "Your father died for his homeland" (226). Jacques knows that he is French. He knows that the word 'patrie' engenders certain duties and sacrifices, but he does not understand the absence of France, a country that he compared to the omniscient God who knows everything at once without acting.

The uncertainties displayed in Camus's discourse, his ambivalence towards France, is intensified by hybridity. For Camus, Algeria is the place where he works, where he had his first responsibilities and lived with the Other; living with the Other is a way to manage the sensitivities. The immediacy of information available to him, as a writer and as a journalist, is evident in his books, where he talks a lot about his Algerian colleagues. He could have kept silent, but speaking of them is a way of also talking about himself, and silence would undermine a part of himself. Unfortunately Camus did not live long enough in order to return to his Algerian past. 
The other is at the same time different and similar, $s /$ he is full of contradictory emotions such as love and hatred. When Camus visits Kabilia as a reporter, and gets into the Zawia of Koukou, a Sufi lodge, he expresses his deep sympathy towards Algerian people. He says: "It seems to me that I deeply understand this country and its people (...) I did not feel my difference with these people who take refuge here to regain a little of themselves" (Chroniques algériennes 89). He assumes that the French should help the indigenous populations preserve their identity. He feels it is the duty of France to help Algerians to remain proud and true to themselves and their destiny. He adds: "These individuals are not inferior, we have to take lessons from them (...) Too many French in Algeria or elsewhere, imagine them as an amorphous mass" (96). Algeria has taught these hybrid authors to view themselves in the mirror of the Other and to see how the Other sees them. They have more than one vision of the reality. The First Man is an autobiographical novel that opens to the autobiographies of others that shows the heterogeneity of the voices in Algeria. Camus says: "Jews, Turks, Greeks, Italians, Berbers, have as much right to claim the leadership of this virtual nation" (Chroniquesalgériennes202). He is for a kind of federation where French and Algerians would have equal rights and voices, asserts that Algeria is the land of their birth, "la terre de leur naissance" for the French Algerians, and gives the example of Switzerland where different peoples live indifferent areas (207). Hybridity shapes Camus's identity and raises his consciousness about himself as a Frenchman among native Arabs.

\section{MOHAMED BEN CHÉRIF: THE DYNAMICS OF CULTURAL HYBRIDITY}

Our second selection that shares the common theme of hybridity is Ben Mostapha, Goumier. From the beginning of the book Ben Mostapha is presented as an outstanding personality, a proud man who knows the great Arab poets who were versed in wars and tribal rivalries. He quotes Al Moutanabi: "The night, the horses, the desert know me, the host, the pen and the book"(27), and Imroulquais and Antar who remain proud and courageous even when approaching death (49). When, one night, Ben Mostapha hears the bird of death singing, which was an ominous event for him, he decides to go to Morocco and he swears to remain faithful to the French to whom he reveals his loyalty with every action and every word. He says to his lieutenant: "I love France with all my heart, and when it sends officers who talk like you, I would like to get killed for it"(55). Ben Mostapha is fascinated by Arab leaders, such as Hamza, the prophet Mohamed's uncle, who died in the battle of Ouhoud, while Hind was cutting his liver and sucking his blood to take revenge from her father's murderer. ${ }^{1}$ Islam remains a treasure for Ben Mostapha, it is engraved inside him. Despite his permanent nostalgia for those who have made Arab civilization, nevertheless Ben Mostapha is aware that the world is now advancing without the Arabs, whom he blames for their innate hatred that devastated their civilization (60-61). Ben Mostapha fights with the French with a lot of fortitude and endurance and is surprised to meet people who have no affinity with them. When, for instance, he hears the Moroccan merchant treating them as infidels, Ben Mostapha becomes frustrated and states:

The flag I serve, protects me. Its folds carry justice, tolerance, the right of the weak, as the flags of our ancestors. I consider it a pious legacy to continue with my limited means their glorious thought. Moreover, the ancestors of these Christians have served our banners marching toward those lights that illuminate today's new world (68).

Ben Mostapha's interaction and exchange with the other results in a 
bicultural identity, manifest in his ability to cross the boundaries of culture, in a process of assimilation rather than "camouflage" (Lacan, qtd in Bhabha 121). His mimicry is intentional as he is far from being an innocent victim of colonization and, together with his hybridity, functions as his survival kit to gain acceptance by the French.

Just like Cormery, Ben Mostapha is in a state of ambivalence due to his constant and difficult adjustment within two different cultures; his homeland is Algeria yet he cannot see it as dissociated from France (77), a country, which he feels morally, committed to, hence his involvement in the French army. In fact, Ben Mostapha is representative of some Algerians who are educated and desire to be part of the French "civilising" project, exactly as promulgated by the general governor Charles Lutaud,, a strong believer of the French civilizing mission, who considered the indigenous' sacrifice of the period between 1911-1918 as a moral obligation, and a kind of ascension to civilisation (Zeghlache). To fit in this civilising mission, Ben Mostapha is ready to make many concessions and so he struggles over his frustrations in the process of acculturation, without breaking with his own cultural traditions. He makes all these efforts, so that France would one day consider him as one of her children and so he always reminds his French captain that his grand father died in their ranks, during the difficult hours of their arrival in Algeria (81).

At the same time, he is convinced that justice, tolerance, and the rights of the weak are the same in all religions (68); the orientalist discourse is very present in this book. The French captain is usually offensive towards Ben Mostapha and his culture, but Ben Mostapha remains placid and tries to reduce tensions when he repeats to his captain the story of those Algerians who were in the French army since 1870. He considers himself the son of France and is not afraid to show his brotherly devotion, courage and pride (82).
Ben Mostapha talks very frequently about his religion, for example he says to the captain that Islam forbids him to touch women. The captain seizes this opportunity to show his misunderstanding and prejudice of Islam: "Your religion forbids harming women? But allows each of you to keep four in a state of slavery: Your principles are like your Koran, where all the precepts contradict from one page to another"(80). Ben Mostapha gives the example of the state of the Arab people before the prophet Mohamed-peacebe upon him-when many girls were buried alive and how the prophet Mohamed saved them by rejecting this tradition. Yet the commander believes that Arabs' hearts are closed due to their sacred book that stands like a barrier between the western and eastern worlds; further still, he claims that Arabs are unable to assimilate: "when we prove to you your illogical thinking, you start shouting: God, Couscous, Mahomet, Burnous Mosque and all kinds of nonsense words which we are not stupid enough to believe in" (81). There are also other exchanges with orientalist sensibilities that show that the commander is aware of Arabic poetry and is fascinated by its rhymes. He expresses his interest in this language that created alone more poetry than the other languages all together; he concludes:

If the expression of thoughts of your fathers was not so complicated in reading, your past would be better known and you might be appreciated. Admit that your writing system contains exclusively consonants, leaving it to the reader to seek the vowels, and consequently the nuances of time, modes, are somewhat disconcerting. (47)

More of a fighter than a thinker, Ben Mostapha finds it hard to continue this conversation, and so responds with a "yes" only.

As soon as Ben Mostapha hears that France was attacked, he forms the first squadron that sails for Marseille. When he arrives, with his friends, they are greeted 
with great enthusiasm. The other troops land at Bordeaux and Toulouse. The beauty of France fascinates Ben Mostapha. He exclaims: "What a beautiful country! That's what the Prussians want to destroy? By my powerful religion, my eyes will never see such sacrilege" (132). Ben Mostapha is outraged to be called Arab when the Germans caught him and this is the case whenever the Zouaves are called Arabs; he is annoyed and reminds them that these Arabs are French soldiers. This is particularly evident in chapter nine, titled "Exile," which recounts the deportation of the Goumiers to Germany while crossing Belgium (139). It is October, the snow is falling, and the soldiers are poorly fed. Whenever the Germans insinuate that Arabs came by force, Ben Mostapha explains that he and his friends are volunteers (140).

Similarly to Cormery, Ben Mostapha's state of ambivalence results from hybridity. Colonization leaves an indelible mark on people. To remain indifferent is almost impossible. There is a constant internal struggle among colonised people particularly among those who had an opportunity to travel to France, like Ben Mostapha, who is always facing and responding to prejudice, and is revolted by the fixed ideas that the French have about the Arabs. He is surprised, for example, by his French captain's non-belief in the Arabs' ability to assimilate; and when he hears of Arabs being stereotyped as lazy and sleepy, he tells them that his faith in God is great. He says: "Our souls remain faithful to God, this God who is not at all hostile to you" (82). Ben Mostapha embodies different cultures that are simultaneous and spontaneous as he constantly tries to assimilate to the Other. His hybridity allows him to cross the bridges of cultural misunderstanding with the Other, thus it is difficult to identify him as Arab as his cultural and natural "twoness" cannot be overlooked. His mastery of the French language, for instance, is so fluent that it surprises French women to the point of one asking him "are you truly Arab?" (158).
The duchesse voices to him her complete ignorance of Arabic culture, while another woman shouts: "in your country, sir, you eat locusts and make your prayer on the terraces!" (158) When he asks her where she heard about that she hesitates and then says: "I read it in Tartarin de Tarascon". (158) Another French woman explains her disagreement with Arabs who are so generous and hospitable that they offer even their wives. Ben Mostapha listens carefully. It is interesting for him to see how the Other sees his culture. It is important for him to explore the Other's gaze. He responds: "but it is with similar legends that we have long been deceived, too, about women in Europe." (159) Another woman expresses her disappointment in the concealment and the covering of Arab women (158-159). Ben Mostapha is disappointed, yet not distressed; he is tolerant as he lives easily the cultural differences, and he is not shy in exposing himself to the Other's critical eye. He thinks that misunderstanding is due to ignorance. As Edward Said argued, this is not a clash of civilisations; it is a "clash of ignorance."

Ben Mostapha is evidence of the existence of multicultural societies where Muslims and Westerners coexist. He tries to destroy the wall of ignorance by raising the Other's awareness about his own culture, and constantly seeks to correct simple misunderstandings. He tries to persuade French women that Arab wives know how sweet it is to be the hidden treasure, the precious being, a delight for man's heart and a joy for his eyes. He does not see any misfortune concerning Arab women (159). He explains that the girl, the innocent soul, is educated so that, the days he is in the presence of her man she beautifies his life. The French women however, are convinced that Arab women are unlucky and destined to live for the pleasure of man who absolutely ignores their minds. They consider Ben Mostapha to be an egotist and dislike his patriarchal tendencies, blaming him and all Arab men for buying their wives like properties. Ben Mostapha, with a 
mocking tone, argues that in Algeria people think that French women buy their husbands, that it is more logical for a man to offer a dowry to his wife (159). Throughout this dialogue Ben Mostapha is clarifying some prejudices to the French women. He tries to adapt and understand the Other. Here, there is a dilemma of assimilation, which is never completely resolved. Ben Mostapha is torn between two ideals, the French and the Arab, but is convinced that access to modernity is through the Other.

Frantz Fanon is aware that French colonization leads to depersonalization, for the system is "hostile to any attempt to put the individual back where he belonged" (53) and thus hybridity is never free of troubles because it is an obligatory ordeal. Jacques Derrida rightly states: "The silence of that hyphen does not pacify or appease anything, not a single torment, not a single torture. It will never silence their memory" (11). Derrida translates hybridity into a hyphen, plus the two words that are linked to it that constitute identity; the ambivalence and trouble of hyphenated identities are expressed by the silence of that hyphen which is not in any way appeasing. The hyphen is, indeed, apparent in the three authors of our selection. It is difficult to separate different cultures and languages in the postcolonial reality of Algeria. It is difficult to measure animosity and admiration toward the other culture in individuals who experience colonialism. These double identities are situated between fear and admiration. The result is somehow a complex compound. Ben Mostapha is a good example that fits Homi K. Bhabha's colonial mimicry: "colonial mimicry is the desire for a reformed, recognizable 'Other', as a subject of difference that is almost the same, but not quite" (Bhabha122).

\section{ELISSARHAÏS: BLURRING CULTURAL BORDERS}

Elissa Rhaïs, our third selection, also recounts the story of a man who has gone to the Great War. Rhaïs, like Camus and Ahmed Ben Chérif, is the product of hybrid cultures, and this is clearly evident in different photographs of her showing her mixed heritage: in some, she is dressed like an Algerian woman, in others she looks French. Though Rhaïs is of Jewish origin, she writes in French to reveal her familiarity with and attachment to Algerian culture. Le Café Chantant is set in Blida, Algeria and narrates the travels of a man who died in the Great War. The book exposes the writer's great understanding of Algerian culture, it recounts a historical fact with all the related memories and the depth of Rhaïs's sympathy with Arab Muslim culture. For example, she faithfully describes the ramadanesque ambiance of the atmosphere during the holy month for Muslims. She portrays the women's youyous, the cries of joy and happiness, the invocations of Allah, the narrow streets, the children in blue gandourahs, the clapping of the small hands marked with henna to the wrists, and the singing of some popular refrains (3).

Though there are a number of Jews who participated in the Great War, Rhaïs has chosen to recount the story of an Arab, the son of Sidi El Haloui, a retired caid. Rhaïs depicts his house as a frightening one, with a melancholic silence, due to the death of Sidi Youcef in the Great War. The mother, Ella Fathma, thanks God in this month of blessing for the end of this war, and works hard to be able to forget her beloved son, who remains there among "the Roumis" (Christians). What is more, since her son's body was never returned to Algeria, her mourning is without a body, without a grave (19), and so the parents' suffering is without limits. Ella Fathma suffers more when seeing her husband, who reminds her of the old saying: "The heart of man is narrow as the heart of the nightingale"(19). She believes that God protected her for having a peaceful soul that sustains her with great courage and patience. She remains strong before her husband but she has aged overnight (25). The couple tries to rebuild after the 
tragedy, but the emotional damage is difficult to repair. Fathma says:

Losing the only son indeed, a son of twenty years (...) And how? Without having seen him sick, without having stayed beside him for a night or an hour, without having given him a drop of water!(...) We do not know where or how, he is lying in an unknown land(...) without a burial stone, without a marabout for protection. (25-26)

A person cannot mourn without having seen the body. Ella Fathma goes regularly to the unknown grave sin the cemetery of Blida to curse those who wanted this war (28).Sidi El Haloui learns that Halima, a very beautiful and famous courtesan was in relationship with his deceased son. When he arrives to see her, Halima was singing the Separation of Lovers. She sings her experience, and her tears overflow her cup. She feels the words that exhale her own suffering. This is perhaps the most moving passage from the book where the artist and the audience are in an absorbing and solemn symbiosis. Rhaïs says:

That night, young and old cried and sobbed headlong (...) They were all more or less affected by the fatal war. And the song The Separation of Lovers, was mostly a tragic death of a son on the land of Roumis, the death of a brother, or a friend violently torn from a faithful and profound affection.(68)

The song has also moved Khoukhdia who is in the same troop of Halima. She has accepted to pay a fine to the boss in exchange for a night with her beloved that she might never see again because he had to fight with the French army against the German occupier (60).

Halima talks to the father about Sidi Youcef and his sudden departure for the Great War. In her novella Noblesse Arabe, Elissa Rhaïs deals again with the Great War and how women in Algeria go through a period of mourning even when they are not immediately concerned with death (157). They wear their white gandourah while asking about those who went to war (156). Elissa Rhaïs' work embodies desire, fantasy, her characters express glimmering depictions of Algerian people and culture that know no boundaries. She is nurtured by the two cultures that formed her identity, integrates the Other's culture easily and is willing to meet them. Writing in French is a kind of assimilation with the French and writing about the Algerians is a kind of assertion of her double belonging. There is an underlying acceptance of the Other to the point that one feels that she is more an insider of the Algerian culture than an outsider. Her work reads as if she is going through an ephemeral path where she shows that she is still a part of the Algerian community.

\section{CONCLUSION}

It is important today to analyze the books that have been thrown into the dustbin of history. Ben Mostapha Goumier is not taught in universities in Algeria. It is not included in the Algerian university syllabus. Some authors have been marginalized and it is so important today to make room for diverse views to re-write the Algerian history by including minority voices especially on important issues such as the Great War.

Sharing three things in common, the same place, the same time, and the same event, the Great War, the three writers discussed in this paper claim for themselves a difference with and an attachment to the French. The three books are between private and collective memory. Most of the time they intensely mirror reality. Although they are not historians, there is a historic dimension in these writers' work. The three writers are struggling between two cultures. They are concerned about where they belong, nevertheless, they try to give an objective perspective in their writings. Studying these types of texts is important as they help to destroy the wall of ignorance between the East and the West and show how hybridity is positive, when there is a discussion between self/Other and 
East/West. All three writers are in the process of engagement with the Other. Hybridity for them constructs a multicultural society; it destroys walls of misunderstanding, facilitates the meeting with the Other, erases inhibitions, and allows collective East/West interconnections. These writers have "a lover's quarrel" with the Other, to paraphrase Robert Frost's poem, an ambivalent attitude toward the Other which is fruitful in the sense that it develops multicultural sensibilities, integration and tolerance.

These books will remain a testimony for all those who have a lot of fear of the Other. Camus states that he has an endless love affair with Algeria, and this is mostly testified in his last book the First Man, where there is always a return to the place where he was born. He answers beautifully his accusation of loving his mother more than justice, by quoting his mother herself: "I want to stay home," "je veux rester chez nous" Le premier homme (89). The three writers would have loved a system whereby France and Algeria remained together in a confederation, a partnership, anything that could join the two countries forever. Camus says: "I tried, in this regard, to define my position clearly. Algeria consists of a federation of peoples, subsequently connected to France" (Chroniquesalgériennes28). $\quad \mathrm{He}$ adds: "If, in Algeria French and Arab fuse their differences, the future will be meaningful for French, Arabs and the entire world" (20).

The three authors use writing to explore their hyphenated identities. They refuse the silence, usually imposed in colonial contexts. The three narratives show how the paths of three men who went to France during the First World War were forced to meet with the Other, an encounter that left indelible marks on the protagonists' identities and their sense of belonging to more than one ethnic group, one country and one linguistic space.

\section{REFERENCES}

Ben Chérif, Mohamed. Ahmed Ben Mostapha Goumier. Publisud, 1997.

Bhabha, Homi. Location of Culture. Routledge, 1994.

Camus, Albert. Chroniques algériennes 1939-1958. Gallimard, 1958.

---. Le premier homme. Gallimard,1994.

Derrida, Jacques. Monolingualism of the Other, or The Prosthesis of Origin. Translated by Patrick Mensah, Stanford University Press, 1996.

Fanon, Frantz. Toward the African Revolution. Translated by Haakon Chevalier, Grove Press, 1964.

Rhaïs, Elissa. Le Café-Chantant. Librairie Plon, 1920.

Déjeux Jean. Littérature maghrébine de langue française. Editions Naaman, 1973.

Said, Edward. "The clash of ignorance."TheNation,http://www.th enation.com/doc/20011022/said, posted on 04 October 2001.

Zeghlache, Mostefa. "Les Algériens et la première guerre mondiale Faut-il commémorer le centenaire de 19141918 ?".El Watan, 13 July 2014,

http://www.lesoirdalgerie.com/articles/2 014/02/06/article.php?sid=160081 \&cid $=41$ 